\author{
放電励起エキシマレーザー発振過程の2次元シミュレーション \\ 山越 英男, 桑田 知江* , 山下一郎*, 加藤 光雄, 牧原 洋* , 辰本 正弘* \\ 三菱重工業株式会社基盤技術研究所（ $\bar{\top} 236$ 神奈川県横浜市金沢区幸浦 1-8-1） \\ *三菱重工業株式会社広島研究所（７７33広島市西区観音新町 4-6-22）
}

\title{
Two-Dimensional Computer Simulation of Discharge Pumped Excimer Lasers
}

\author{
Hideo YAMAKOSHI, Chie KUWADA*, Ichiro YAMASHITA*, Mitsuo KATO \\ Hiroshi MAKIHARA*, and Masahiro TATSUMOTO* \\ Advanced Technology Research Center, Mitsubishi Heavy Industries, Ltd. \\ 1-8-1 Sachiura, Kanazawa-ku, Yokohama Kanagawa 236 \\ *Hiroshima Research and Development Center, Mitsubishi Heavy Industries, Ltd. \\ 4-6-22 Kanon-Shinmachi, Nishi-ku, Hiroshima 733
}

(Received July 22, 1996)

\begin{abstract}
A two-dimensional simulation code of a discharge-pumped excimer laser was developed to study the effect of spatial discharge non-uniformity on laser output performance. The code consists of a circuit equation, a continuity equation to calculate two-dimensional electric field, a steady-state Boltzmann equation, and rate equations. The preionization distribution was found to affect the electron and the excited particle distributions and hence the laser beam profile. Even with uniform-field electrodes, the calculated electric field distribution was not uniform, being effected by the configuration of surrounding structures, and varying in time with the changing discharge plasma conditions. The electric field surrounding insulating structures were found to increase prior to gas breakdown and to decrease afterwards.
\end{abstract}

Key Words: Excimer laser, Two-dimensional simulation, $\mathrm{XeCl}$, Electric field, Preionization

1.はじめに

紫外域において高効率で発振する放電励起エキシマ レーザーは,リソグラフィーなどの超微細加工, アブレー ションによる新材料創製など様々な分野に利用されてい る。これまで,大出力化などを目指した開発が行われる一 方, 発振特性予測を目的とした理論解析コードが開発され てきた。1978年にGreenら1)によって最初のコードが作成 され, 国内では水波ら ${ }^{2)}$, 外園ら ${ }^{3)} に よ り$ 同種のコードが作 成されている。この種のコードでは回路方程式, 電子エネ ルギー分布を記述する定常ボルツマン方程式, 各種粒子(原 子, 分子, イオン, 電子) の反応と光共振器内の光子の増減 を記述するレート方程式を並列に解くことにより, 時々変 化する放電電界, 粒子ならびに光子の生成 · 消滅, および レーザー出力が計算される。これらにより, 回路構成, 電 源電圧, 電極間距離やレーザー媒質ガスの組成, 圧力のレー ザー特性への影響が予測され, 高効率化などへの指針が示 されてきた。また, 最近Sorkinaらは, スパイカーーサステ イナー回路を用いた弱励起のXeClレーザーを対象として, 励起強度に対する出力特性を予測し, 実験結果との良い一 致を得ている4).

しかしながら一般には,これらのコードで予測される
レーリ゙ー特性は, 実際の实験結果と定性的には一致するが, レーザー出力が実際より大きく計算されるなど, 定量性は それほど良いとは言えない。この原因として, (1)放電が空 間的に均一と仮定していること,(2)放電過程のモデル化が 充分でないことなどが考えられる。(2)では,実測される電 子エネルギー分布が従来のコードで予測される分布より もマックスウェル分布に近いことが分かってきており， コードの改良が進められている3,5). 著者らのグループも トムソン散乱法による電子エネルギー分布, 電子密度の測 定結果と解析結果の比較を行って, コードの改良を進めて いる6). (1)については, 電極形状, 予備電離分布などによる 空間的な放電状態の影響や, 放電の不安定性(アーク放電の 発生)による局所的な不均一性の影響を模擬できないこと が問題となっており, 空間分布を考慮した解析が必要とさ れている。

放電励起エキシマレーザーでは, 均一で幅の広い放電に より，良質なビームパターンで高効率な出力が得られるこ とが多い。そこで,均一な電界を得られるErnst型電極など を用いたり,定常電界の2次元計算を行ったりしている7,8). しかし, 放電により電界が変化するため, 電極形状の放電 への影響は定常解析では充分ではない. したがって, 電極 形状などを適正化するためには, 放電分布を考慮したコー 
ドが必要である。また, 予備電離の適正化にも空間分布を 考慮する必要がある。

このような解析としてKushnerらにより2つの2次元解 析9,10) が報告されている.1つは, 2 次元断面を適当に短冊 状に切って電流路とし, それぞれの電界強度から放電状態 を計算している9 。この方法は電流路をあらかじめ決める ので, 正確な計算はできない.もう一つは, 電子ビーム維 持放電を対象として電流の連続性により電界を計算して いる10).しかし, 通常のエキシマレーザーでは放電初期に は電流の連続性が成り立たず, 放電初期に影響が大きい予 備電離や放電部構造の検討には不十分と考えられる.

一方, 明石らは放電進展を模擬する空間分布解析11) Fang らは不安定共振器型でのレーザー光の増幅の空間解 析12)を報告しているが,これらは1次元である.

本論文では, 放電の空間分布のレーザー特性への影響を 検討するために, エキシマレーザーの2次元コードを作成し た。電界分布を求めるための伝導電流と変位電流の連続 の式とその有限要素法による解法は, 今回新たに採用した ものである。

\section{2. 理論解析モデル}

今回のモデルは従来の空間均一のモデルを2次元化した もので, (i) 電極間電圧を求める回路方程式, (ii) 電界分布を 計算する連続の式, (iii) 電子衝突の反応定数を求める定常 ボルツマン方程式, (iv) 粒子間の化学反応, 光子の増減を計 算するレート方程式からなり,これらを連成してパルス発 振を計算する.2次元空間はレーザー光軸(電極の長手方 向)に垂直な断面とし,光軸方向は均一とした. 計算の流れ をFig.1に示す。

電界分布を計算する(ii)の連続の式は以下のように導出 した．まず,体積放電であるので磁界は小さいとして無視 するとマクスウェル方程式から以下の3式が得られる。

$$
\begin{aligned}
& \boldsymbol{\nabla} \cdot \boldsymbol{D}=\rho \\
& \boldsymbol{\nabla} \times \boldsymbol{E}=0 \\
& \boldsymbol{\nabla} \cdot\left(\boldsymbol{J}+\frac{\partial \boldsymbol{D}}{\partial t}\right)=0
\end{aligned}
$$

$\boldsymbol{D}$ は電束密度, $\rho$ は電荷密度, $\boldsymbol{E}$ は電界強度, $\boldsymbol{J}$ は伝導電流密 度, $t$ は時間である。（3）はべクトル公式から得られ, 括弧 中の各項は伝導と変位電流を示す。（1）を代入すると,

$$
\boldsymbol{\nabla} \cdot \boldsymbol{J}+\frac{\partial}{\partial t} \rho=0
$$

となって, 電荷連続の式を得る。パルス放電の間イオンは 動かないと仮定すれば, 伝導電流密度 $\boldsymbol{J}$ は電子のみを考慮 して次式で表される。

$$
\boldsymbol{J}=\rho_{\mathrm{e}} \mu_{\mathrm{e}} \boldsymbol{E}
$$

$\rho_{\mathrm{e}}=-N_{\mathrm{e}} \mathrm{e}$ は電子による電荷密度, $N_{\mathrm{e}}$ は電子密度, $e$ は素電荷, $\mu_{\mathrm{e}}$ は電子易動度である。そして, (2) 式が成り立つようにポ テンシャル $\phi$ 導入し, (3) 式を変形すると,

$$
\nabla \cdot\left(\rho_{\mathrm{e}} \mu_{\mathrm{e}} \nabla \phi+\varepsilon \nabla \dot{\phi}\right)=0
$$

が得られる，ยは真空の誘電率である。（2）式が成り立つ ためには磁界が小さく無視できる必要がある。そこで, 計 算結果から磁界を計算し, 無視できることを確認した。

放電解析ではKushnerらが行ったように10),(6)式第1項の 伝導電流の連続を解く場合が多いが,ここでは絶縁破壊前 に大きく影響する変位電流を考慮するために, 第2項も含め た（6)式を解いた，絶縁物の部分は伝導電流が無く,変位電 流のみであるから，

$$
\nabla \cdot\left(\varepsilon_{\mathrm{D}} \varepsilon \nabla \dot{\phi}\right)=0
$$

を解いた。 $\varepsilon_{\mathrm{D}}$ は絶縁物の誘電率である。解法はGalerkin法 を適用した有限要素法で, 三角形一次要素 (以下, セル)を 用い, 非定常項は差分法(Crank-Nicolson法)で近似した。陰 極上のシースは非常に薄く11)，これを正確に解くためには セルを非常に小さくしなければならない。しかし,シース での電圧降下は全体と比較して小さいと考えられるので, シースは直接解かず大きなセルを用いた。セル分割の例 をFig.2に示す。

陰極電子放出にはこのシースが影響する。また，もう一 つの放出機構である光電子放出もモデル化が難しい. そ こで, 電子放出には近似モデルを採用することにした。両 極端の場合として, (a)電子放出無, (b) 電界に対応し自由 に放出,の2モデルを計算した．出力, 放電幅などは变化な かったが,出力分布では (b) は陽極から陰極まで均一である のに対し (a)では㓌極近傍に強度のばらつきがあった。対 象とした実験でも(a)のような焼きパターンが観測された ので, (a)をモデルとして採用した.

計算は以下のように行った(Fig.1)。まず, ある時刻の放 電電流 $I_{\mathrm{d}}$ と放電電圧 $V_{\mathrm{d}}$ からオームの法則で放電抵抗 $R_{\mathrm{d}}$ を求 め, (i) に代入して次の時刻の $V_{\mathrm{d}}$ を求める。次に, (iv) から

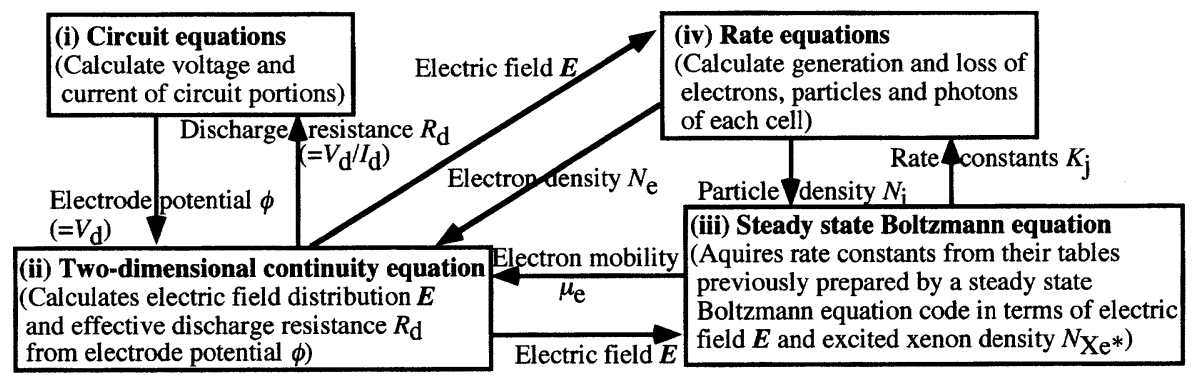

Fig.1 Configuration of the two-dimensional simulation code for discharge pumped $\mathrm{XeCl}$ excimer lasers. 


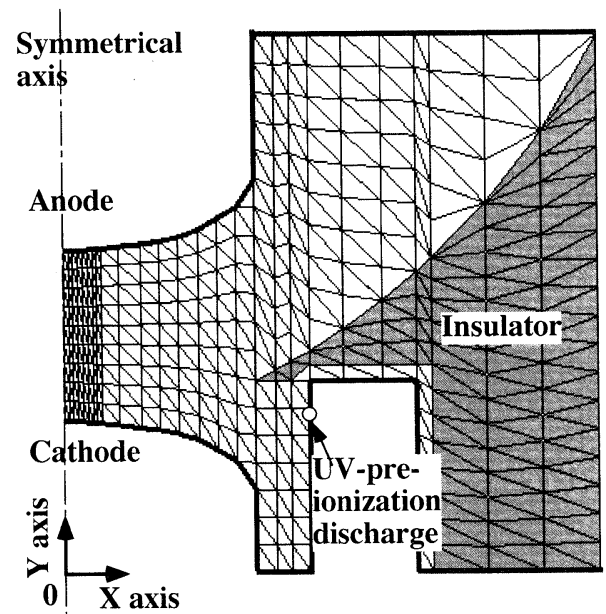

Fig.2 Example of mesh used for the calculation. Only the right half of the discharge region was calculated because the region is symmetric. Boundary potentials calculated by the circuit equations are given at thick solid border lines (top: anode, bottom: cathode). Thin solid border lines are free boundaries. The rectangle swell at the bottom is a surface of a UVpreionization assembly where the cathode potential was assumed. Darken cells represent an insulator.

求められる電子密度 $N_{\mathrm{e}}$, (iii) から求められる電子易動度を （ii）に代入し電位 $\phi$ を求める。境界条件は(i) から求められ る $V_{\mathrm{d}}$ をアノード側 $\phi=V_{\mathrm{d}}$, カソード側 $\phi=0$ と与え, それ以 外は自然境界(伝導十変位電流の流出入ゼロ)とした。 $\phi$ か ら電界 $\boldsymbol{E}$ と放電電流 $I_{\mathrm{d}}$ を求める。電界計算は絶縁破壊前後

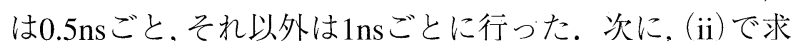
めた各セルの電界 $\boldsymbol{E}$ を用いて, 各セルごとに(iii)で電子エネ ルギー分布を求め, 電子衝突の反応定数と電子易動度を求 めた。隣のセルから流入する電子のエネルギー分布の影 響は無視した。解法は均一解析 ${ }^{2)}$ に習い, 衝突断面積は Ohwaら 13)に従った。（iii）は各時刻に各セルで解くと時間 がかかるので, 電界強度 $\boldsymbol{E}$ と準安定準位Xe原子密度に対す るテーブルをあらかじめ作っておき, 補間して用いた。各 セルごとに反応定数を(iv)に代入し, 粒子間の化学反応, 光 子の増減を計算した。電子のレート方程式には, 粒子との 衝突による増減の他に, (5)式の伝導電流に相当する電子の 移流項と, 予備電離による電子の生成項を加えた。電子の 拡散は無視した。移流項は,

$$
\frac{\mathrm{d} \boldsymbol{N}_{\mathrm{e}}}{\mathrm{d} \boldsymbol{t}}=\frac{l}{S} \mu_{\mathrm{e}} N_{\mathrm{e}}(\boldsymbol{E} \cdot \boldsymbol{n})
$$

をセルの各辺について足し合わせた。lはセルの辺の長さ， $S$ はセル面積, $\boldsymbol{n}$ は法線ベクトルである。空間と絶縁物の境 界においてはシースが生じると考えられるが, 今回は電束 密度の差に相当する表面電荷 $\sigma=\varepsilon_{\mathrm{D}} \boldsymbol{E}_{\mathrm{D}} \cdot \boldsymbol{n}-\varepsilon_{0} \boldsymbol{E}_{0} \cdot \boldsymbol{n}$ が生じ るとして, その増減を空間部分の電子密度变化とした。 レーザー出力は各セルの光子密度から計算した. 反応定 数はOhwaら ${ }^{13)}$ に従った。レート方程式は差分法で, 刻みは $0.025 \mathrm{~ns}$ 程度とし, 絶縁破壊前後は細かくして計算するとと もに, 安定に解が求められることを確認した。

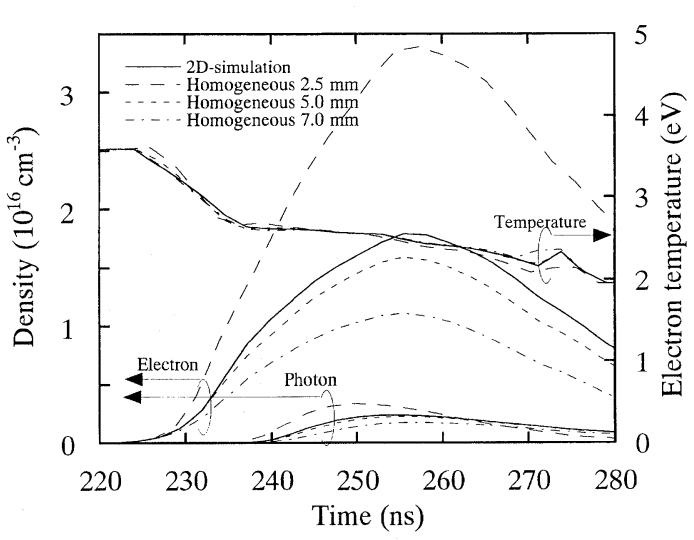

Fig.3 Time histories of electron density, photon density and electron temperature. Solid line represents the result of the 2D simulation while three dotted lines represent those of homogeneous simulations calculated respectively with different discharge width.

\section{3. 結果と考察}

計算対象は容量移行型放電励起XeClエキシマレーザー で, ガス組成Xe/HCl/ $\mathrm{Ne}=30 / 3 / 4560 \mathrm{Torr}$, 充電電圧 $30 \mathrm{kV}$, ス トレージ容量 $129 \mathrm{nF}$ ，ピーキング容量 $119 \mathrm{nF}$ ，電極は間隔 $22 \mathrm{~mm}$, 長さ $92 \mathrm{~cm}$, 幅 $5 \mathrm{~cm}$ の Ernst型15)である. 予備電離分布 は3.2章での検討の場合を除き, 均一に $10^{8} \mathrm{~cm}^{-3}$ 与えた。

\section{1 空間均一解析との比較}

まず, 2 次元解析 (以下, 2 次元) と従来の均一解析 (以下, 均 一) を比較した. Figure 3 に電子密度. 光子密度, 電子温度 の比較を示す. 実線は2次元の電極間中央の值, 点線は均一 で放電幅が2.5, 5.0, 7.0 mmの結果である。均一で5.0mmの ときが2次元とほぼ一致している。このとき,電圧, 電流の 時間変化も一致した. 出力は2次元がやや小さめであった が, 同様の時間変化を示した。すなわち, 2 次元と均一で大 きな結果の違いはないが, 均一では放電幅に適切な值を与 える必要があるのに対し, 2次元では放電幅を与えずに自動 的に放電状態の計算を行うことができるようになった。

また, 分布が計算されることにより出力の計算精度も向上 したと考えられる。

ところで, 1章で述べたように著者らはトムソン散乱法 により電子エネルギー分布計算モデルの評価を進めてい る.トムソン散乱法では, $S / N$ 比が高い電極間中央部しか計 測できない. 本来この結果は2次元解析結果と比較すべき であるが, 電子一電子衝突を考慮するために計算が複雑と なるため, 計算時間の短い均一解析を用いている. 上記か ら,このような場合でも適切な放電幅を選べば, 均一解析 を用いてよいと考えられる。

\section{2 予備電離分布の放電への影響}

予備電離の効果には, (1)局所的な不均一性(ストリーマ放 電)を防ぐ初期電子の生成, (2)分布の主放電への影響, があ る. (1)のための閾值は $10^{7} \mathrm{~cm}^{-3}$ 程度で13) $10^{8} \mathrm{~cm}^{-3}$ 以上が安定 な放電のために必要と考えられている。本コードでは(1) は模擬できない.そこで以下では, (1)が満足された安定な 
条件下で(2)がどう影響するかを検討する。

まず,均一に予備電離した場合の電離密度による出力変 化を調べた． $10^{6} \sim 10^{8} \mathrm{~cm}^{-3}$ の範囲ではほとんど変化がな かった. $10^{10} \mathrm{~cm}^{-3}$ では予備電離を強くしたにもかかわらず 約5\%の出力が低下した。これは, 放電抵抗が低くなり,工 ネルギー注入が減少したためと考えられる。しかし, 安定 な放電のためには強い予備電離をした方がよいと考えら れる。

次に, Taylorらの予備電離実験13)にならって, 分布を変化 させて検討した。 まずX方向(Fig.2で定義)を変化させた. $\mathrm{X}=1.5 \sim 3.0 \mathrm{~mm}$ をステップ部として密度を変化させ, 他の 部分を $10^{8} \mathrm{~cm}^{-3}$ とすると,ステップ部が小さい $\left(10^{6} \mathrm{~cm}^{-3}\right)$ 場合 には, 他の部分 (中央部)に放電が集中し, ステップ部は出 力が得られなかった。これはTaylorの実験結果と一致して いる. ステップ部の電子密度増加が他の部分と比べて少 ないのが原因である．逆にステップ部を大きく $\left(10^{10}\right.$, $\left.10^{12} \mathrm{~cm}^{-3}\right)$ すると, 放電とレーザー出力がそこに集中した. このように, 予備電離分布により出力分布を変化させられ ることがわかった。そこで, 出力幅を広げることを目指し て, 中央部を $b\left(10^{8} \mathrm{~cm}^{-3}\right)$ とし $X=25 \mathrm{~mm}$ まで傾き $a\left(\mathrm{~cm}^{-3} / \mathrm{mm}\right)$ で単調増加する予備電離 $N_{\mathrm{e}}(X)_{\mathrm{t}=0}\left(\mathrm{~cm}^{-3}\right)$ を仮定した。

$$
\begin{aligned}
& N_{\mathrm{e}}(X)_{\mathrm{t}=0}=a|X|+b \quad(|X|<25 \mathrm{~mm}) \\
& =b \quad(|X| \geq 25 \mathrm{~mm})
\end{aligned}
$$

これに近い分布はUV予備電離などでも得うる。これによ

り, Fig.4に示すように出力幅が広がった.

次に, $Y$ 方向分布として, 陰極表面から8.6 13.4mmの電 極間の中央部分に $10^{6} \mathrm{~cm}^{-3}$ をえ, 他の部分に $10^{8} \mathrm{~cm}^{-3}$ をえ た場合と $10^{8} \mathrm{~cm}^{-3}$ で均一な場合を比較した。ステップ部が 弱い場合にはその部分の出力が低下し, Taylorの実験結果 と一致した. ステップ部の陽極側は, 電子の流入が少ない にもかかわらず,均一な場合と出力が変わらなかった。こ れは, 電子がほとんど動かず (電子のドリフト速度は数 $\mathrm{cm} / \mu \mathrm{s})$ に周囲の原子と衝突を繰り返して増減する状態にあ り,その増減はその場での電離と再結合によって支配され ているためと考えられる。これは高気圧体積パルス放電 の特徴と考えられる.

\section{3 放電部構造の放電への影響}

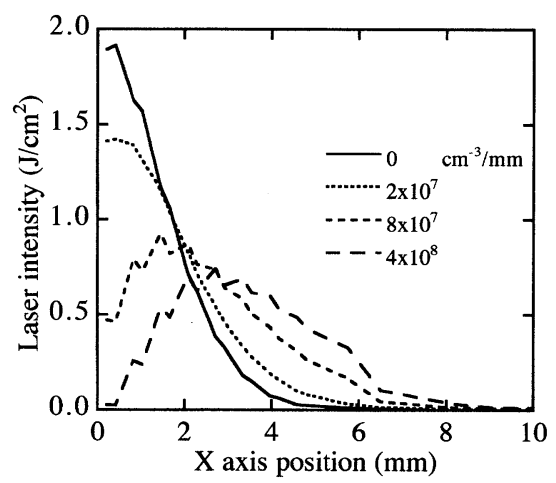

Fig.4 Laser intensity distribution along the $\mathrm{X}$ axis. Assumed preionization electron density distributions are defined as Eq. (9) with indicated coefficients $a$.

\subsection{1 電位分布の時間変化}

Figure 5に電位分布を示す. Figure 5 (a)の絶縁破壊前は (6)式の第1項の電子密度 $\mathrm{N}_{\mathrm{e}}$ は無視できるほど小さく, 変位 電流に支配され, Sato ${ }^{6)}$ PLazzaro $^{7)}$ の様に静電界を解いたも のに近い. 比較的均一な分布であるが, 周囲の予備電離部 や絶縁物の影響を受けている，放電部の設計にはこれら の影響を考慮する必要がある。

絶縁破壊が起きると（6)式第1項が無視できなくなり， Fig.5 (b)のように電位分布が大きく変化する. その後, 伝 導電流の連続性が電位分布を支配し, 周囲にあまり影響さ れない均一な分布となる。これは, 電子の生成, 消滅と電 界強度の増減がバランスし, 電位分布が均一になる方向に 系が動くためである。このように電位分布が放電により 変化するので,出力分布の予測にはこのような解析が必要 であると考えられる。

\subsection{2 絶縁物の影響}

Figure 5の構造では, 予備電離ピンと陽極間の絶縁破壊を 防ぐために絶縁物を設置している。（6)式と（7)式を比べる と, 絶縁物の方が空間よりも誘電率 $\varepsilon$ が大きいので, 絶縁 破壊前の伝導電流が無視できる状態では絶縁物中の電界 が弱くなる(Fig.5 (a))。この状態では周囲の電界が強くな るので, 金属と絶縁物で囲まれた狭い空間などで局所的に 放電がおこ万可能性がある

電子密度が増え空間の電界が伝導電流で支配されて来 ると, 空間の電界強度が低下し, 絶縁物に電界が集中する。

Figure $5(\mathrm{~b})$ の予備電離ピンと陽極間にこの現象が見られ る. 絶縁物の周囲の空間の電離が抑制されて, 絶縁破壊が

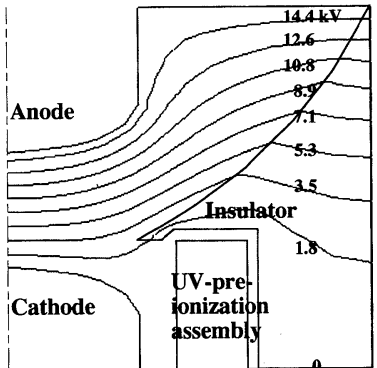

(a)

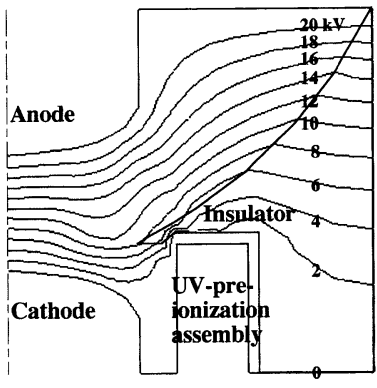

(b)
Fig.5 Variation of potential distribution with time. (a) Before gas breakdown (180ns from the start of applying voltage). (b) After the gas breakdown (220ns).

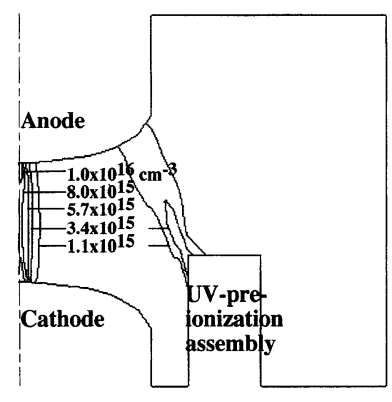

(a)

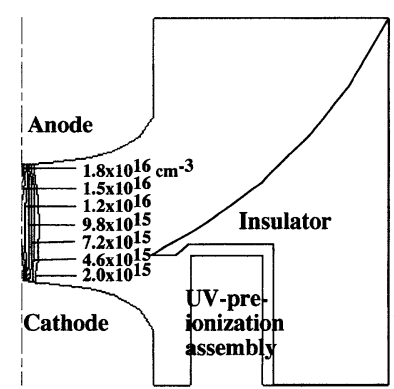

(b)
Fig.6 Electron density distributions after the gas breakdown (220ns). (a) Without insulator. (b) With insulators. 


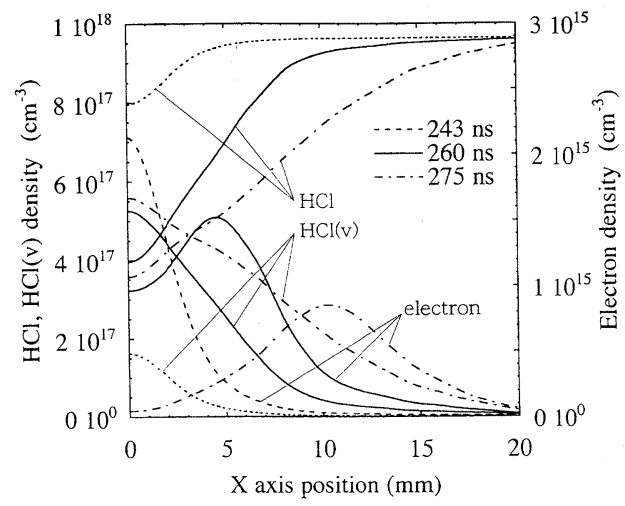

Fig.7 $\mathrm{HCl}, \mathrm{HCl}(\mathrm{v})$ and electron density distribution along $\mathrm{X}$ axis before, at and after the discharge peak (time $=$ $260 \mathrm{~ns})$ in the case of high initial $\mathrm{HCl}$ concentration (30 Torr).

防がれる. Figure 6に絶縁物が存在する場合としない場合 の絶縁破壞後の電子密度分布を示す。パルス放電である ため絶縁物があっても変位電流によって電流が流れるが, 絶縁物によって陽極と予備電離部の間の放電が抑制され ている。絶縁物に電界が集中して放電電圧のかなりの割 合が絶縁物にかかるので, 注意して設計する必要がある。 薄い絶縁物を用いると穴が開くことがあるが, これは, 薄 いと空間の電界を緩和できず, また, 絶縁物に電界が集中 してしまうためと考えられる.

\section{4 ハロゲン濃度の放電不安定性八の影響}

実験ではハロゲン濃度を高くすると放電が不安定にな り出力が低下する。これは, 放電が進むにつれて電子を付 着するべきハロゲンが局所的に枯渇し, その領域の電子密 度が暴走し, フィラメンテーションが生じるためであ る ${ }^{14,16)}$ ，そこで, その様子を模擬した，ところが, $\mathrm{HCl}$ 濃度 を高くしたときのHClの局所的減少は, $\mathrm{HCl}$ 濃度が低い場合 よりも穏やかであり, 電子密度の暴走は模擬できなかっ た. Figure 7に $\mathrm{HCl}$ 30Torrに高くした場合の $\mathrm{HCl}, \mathrm{HCl}(\mathrm{v})$, および電子のX軸方向分布を示す，時間とともに中央付近 のHCl濃度が減少しているが, その代わりに付着確率が $\mathrm{HCl}$ よりも高い $\mathrm{HCl}(\mathrm{v})$ が増加しているために, 電子密度は暴走 せずにむしろ中央付近で減少し, ピーク位置が放電幅方向 に移動している、レーザー出力はHCl分圧3Torrの時と比べ て半分ほどに減少したが, これはFig.8に示したXeCl*密度 とレーザー出力パワー分布の時間変化からわかるように, 放電の強い領域の移動につれてレーザー出力の領域が移 動する過程でのロスが原因であり,フイラメンテーション が原因のロスではない. 今後, 陰極のホットスポットや,ア バランシェ過程での確率的要因, 予備電離の不均一性など のモデル化により,フィラメンテーションを模擬できる コードとする必要があると考えられる。

\section{4. おわりに}

放電励起エキシマレーザーの2次元解析コードを作成し た. 従来は入力として与えていた放電幅が自動的に計算 されるようになった。 また, 以下の知見が得られた。

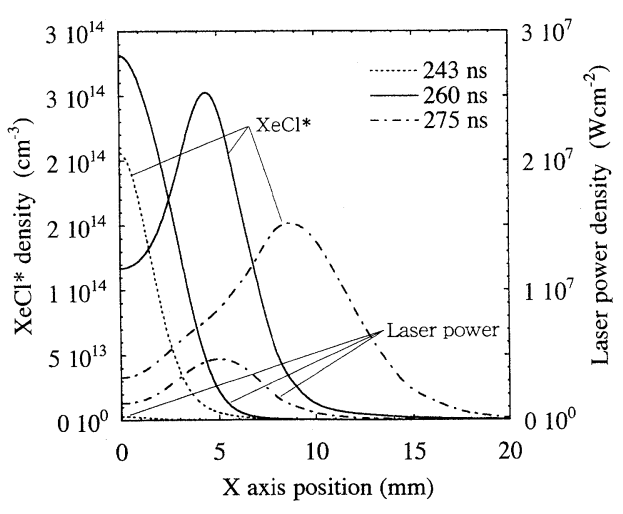

Fig. $8 \mathrm{XeCl}^{*}$ density and laser power intensity distribution along $\mathrm{X}$ axis in the case of high initial $\mathrm{HCl}$ concentration (30 Torr).

1)予備電離分布は放電分布および出力分布に影響を与え る.

2)均一電界電極でも周囲の構造によっては均一な電界が 得られない.

3）プラズマ状態の変化にともない, 電界分布は静的な分布 から大きく変化する。

4) 絶縁物は, 周囲の電界を破壊前は強め, 破壊後は緩和す る効果がある。

しかしながら, 高八ロゲン濃度での放電不安定性のよう な, 極局所的な不均一性を原因とする放電状況は, 今回の 2次元解析モデルでは模擬できなかった. 今後,このモデル 化が必要と考えられる。

\section{謝 辞}

本論文をまとめるに当たり貴重なご助言をいただいた 九州大学村岡 克紀教授, 前田 三男教授, 三菱重工業 (株) 水井順一博士に感謝いたします。

\section{参考文献}

1) A. E. Green and C. A. Brau: IEEE J. Quantum Electron. QE-14 (1978) 951.

2) 水波徹, 前田三男, 内野修, 下村修, 宮副泰：レーザー研究 9 (1981) 527.

3) H. Hokazono, K. Midorikawa, M. Obara, and T. Fujioka: J. Appl. Phys. 56 (1984) 680.

4) R. Sorkina, F.A. van Goor, and W. J. Witteman: Appl. Phys. B 55 (1992) 478.

5) F. Kannari and W. D. Kimura: J. Appl. Phys. 64 (1988) 500.

6) K. Uchino, T. Kubo, H. Dozono, H. Yamakoshi, M. Muraoka, M. Maeda, A. Takahashi, and M. Kato: Appl. Phys. B 61 (1995) 165.

7) T. Sato, K. Miyazaki, T. Hasama, I. Yamashita, M. Kato, S. Takahara, and J. Mizui: LEOS '89 UV2.1 (1989) 383.

8) P. Di Lazzaro, G. Giordano, L. Mezi, and C. E. Zheng: Optics and Laser Technology 26 (1994) 15.

9) M. J. Kushner, A. L. Pindroh, C. H. Fisher, T. A. Znotins, and J. J. Ewing: J. Appl. Phys. 57 (1985) 2406.

10) M. J. Kushner: J. Appl. Phys. 62 (1987) 101.

11) 明石 治朗, 伊達広行, 酒井 洋輔, 田頭博昭: 電気学会放電研 究会資料 ED-92-105 (1992) 107.

12) H. Fang and M. R. Perrone, IEEE Quantum Electron. QE-30 (1994) 2369.

13) M. Ohwa and M. Obara: J. Appl. Phys. 59 (1986) 32.

14) R. S. Taylor: Appl. Phys. B 41 (1986) 1.

15) Gerard J. Ernst: Opt. Lett. 49 (1984) 275.

16) M. R. Osborne: Appl. Phys. B 45 (1988) 285. 